\title{
RES MEDICA
}

Journal of the Royal Medical Society

\section{Society News}

\section{The Editor}

\author{
Abstract \\ MEMBERS OF COUNCIL FOR THE 245th SESSION 1981/82
}

The following members of Council were elected at the AEGM held on Wednesday, 20th May, 1981

Senior President

1st Junior President

2nd Junior President

3rd Junior President

Senior Secretary

Junior Secretary

Convenor of the Business Committee

Convenor of the Publicity Committee

Convenor of the House Committee

Convenor of the Library Committee

Convenor of the Museum Committee

Convenor of the Entertainments Committee

\author{
Brian Montgomery \\ Alastair McKinlay \\ Hamish McRitchie \\ John Frater \\ Shona Ross \\ Aileen Van der Lee \\ Christopher Ingamells \\ Andrew Hoyle \\ Roderick Elliott \\ Elizabeth Boyter \\ Sandra Brown \\ Dr Richard Elliott
}

\section{NON -COUNCIL POSTS}

Editor of Res Medica

Convenor of the Annual Dinner Committee

Chairman of the Medical Faculty Ball Committee
John Frater

Lyn McLarty

Shona Ross

Copyright Royal Medical Society. All rights reserved. The copyright is retained by the author and the Royal Medical Society, except where explicitly otherwise stated. Scans have been produced by the Digital Imaging Unit at Edinburgh University Library. Res Medica is supported by the University of Edinburgh's Journal Hosting Service: http://journals.ed.ac.uk

ISSN: 2051-7580 (Online) ISSN: 0482-3206 (Print)

Res Medica is published by the Royal Medical Society, 5/5 Bristo Square, Edinburgh, EH8 9AL

Res Medica, 1981: 55

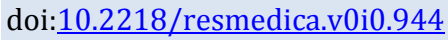




\title{
SOCIETY NEWS
}

\section{MEMBERS OF COUNCIL FOR THE 245th SESSION 1981/82}

The following members of Council were elected at the AEGM held on Wednesday, 20th May, 1981

\author{
Senior President \\ 1st Junior President \\ 2nd Junior President \\ 3rd Junior President \\ Senior Secretary \\ Junior Secretary \\ Convenor of the Business Committee \\ Convenor of the Publicity Committee \\ Convenor of the House Committee \\ Convenor of the Library Committee \\ Convenor of the Museum Committee \\ Convenor of the Entertainments Committee
}

Brian Montgomery

Alastair McKinlay

Hamish McRitchie

John Frater

Shona Ross

Aileen Van der Lee

Christopher Ingamells

Andrew Hoyle

Roderick Elliott

Elizabeth Boyter

Sandra Brown

Dr Richard Elliott

\section{NON-COUNCIL POSTS}

Editor of Res Medica

Convenor of the Annual Dinner Committee

Chairman of the Medical Faculty Ball Committee

\author{
John Frater \\ Lyn McLarty \\ Shona Ross
}

Trust Fund Committee: Since the death of Sir Derrick Dunlop, the Committee has been under the Chairmanship of Prof. David Simpson. Dr. Jack Cormack is welcomed as the new Joint Treasurer - helping Mr. lain MacLaren in this difficult task.

Travel Fund: This scheme - discontinued in 1974 - has restarted under the supervision of the Trustees. It is available to members of one or more years standing. This year $£ 500$ was divided between five applicants.

Library/Museum: Many of the old and valuable books have been rebound and are now in new bookcases. The museum has acquired some tape-slide equipment for members' use.

\section{BIRTHS}

To Dr Andrew Norton (Soc Ord) and Dr Beverley Norton (Olim Praeses, Trustee): a daugher, Zoe. To Lord Perry (Fellow, Chancellor of the Open University) and Lady Perry (Dr Cathering Crawley

(Soc Ord)): a daughter, Jennifer.

\section{ENGAGEMENTS}

Dr. Stuart Blackie (Soc Ord) to Miss Clair Moffett.

Mr. Ian Davies, BDS to Dr. Pamela Brown (Soc Ord).

Dr. Richard Elliott (Olim Praeses) to Miss Elizabeth Boyter (Librorum Custos).

Dr. Graeme Foubister (Soc Ord) to Dr. Susan Mutch (Soc Ord).

Mr. Peter Liston, BDS (Soc Ord) to Miss Carolyn King (Soc Ord).

\section{MARRIAGES}

Mr. Peter Claisse to Miss Zöe Trickett (Soc Ord).

Dr Ron Edwards (Soc Ord) to Dr. Rae Brown (Soc Ord).

Mr. John Frater (Soc Ord) to Miss Susan Chapman (Soc Ord).

Surg. Lieut. Simon Glover (Olim Praeses) to Miss Jane Petrie (Soc Ord).

Mr. Alex Hamilton (Praeses) to Miss Shona Ross (Aedile).

Mr. David Miller to Miss Lyn McLarty (Scriba).

Dr. Robin Mitchell (Olim Praeses) to Dr. Diana Robertson (Olim Praeses).

Dr. Michael Winter (Soc Ord) to Miss Margaret MacLean (Soc Ord). 